\title{
The Effect of Willingness to Participate in Family Value to Intergenerational Learning Program among College Students
}

\author{
Yu Jen Lin and Tai-Fen Chen
}

\begin{abstract}
The Purpose of the study aimed to know college students' willingness to participate in family value to intergenerational. To investigate college students' willingness, the researcher designed the questionnaire after reviewed related literature. The questionnaire's reliability and validity were established through item analysis and factor analysis of the pilot study. A private university students were invited to complete the questionnaire. The researcher purposive sampled the college students to complete the questionnaire. Six hundred and sixty-eight questionnaires were collected. The researcher used descriptive statistics, standard mean deviation, on-way ANOVA, contingency coefficient, and multiple regression analysis to analysis the data. Five research findings of the current study were 1) College student's family value were tended to be traditional especially in the domain of family value but tin the domain of gender role was more modern. 2) In family value, significant differences were found in different gender and school years. 3) College students were lacked of knowledge about intergenerational learning program. 4) In the willingness of taking intergenerational learning program, significant differences were found in different genders, school years, and family types. 5) College students' family value and their willingness of participation intergenerational learning program were positively correlated.
\end{abstract}

Index Terms-College students, family value, intergenerational learning program.

\section{INTRODUCTION}

Taiwan's long-term birth rate decline and average life expectancy have increased, resulting in a year-on-year decline in the proportion of young people aged 0-14, and the proportion of elderly people over 65 years old has increased year by year. According to the specific data, the number of elderly people over 65 years old is 3.31 million, accounting for $14.1 \%$ of the total population; that is, Taiwan officially entered the aged society (Statistics Department of the Taiwan's Ministry of the Interior, 2018). [1]

However, Aged society changed family appearance, from the family organization pattern of the Taiwan from 2001 to 2016 (Table I), it can be seen that the family pattern in

Manuscript received March 4, 2019; accepted September 12, 2019

$\mathrm{Yu}$ Jen Lin is with Hou-Zong Senior High School, Taiwan (e-mail: overdrivecrazy@gmail.com).

Tai-Fen Chen is with Graduate Institute of Education, Tunghai Universtity, Taichung, Taiwan (corresponding author; e-mail: daphnechen@go.thu.edu.tw).
Taiwan has always been the highest proportion of nuclear families, but the proportion of nuclear families has declined in the past 15 years. The trend has been reduced by about $11 \%$. On the contrary, the proportion of singles, couples, single parents and other family types has risen upwards. Among them, the proportion of couples and families has increased most. The main reason for this phenomenon comes from the changes in the social and economic environment, such as the extension of the years of education for young people, the delay in the age of marriage, the decline in fertility rate, the increase in the divorce rate and the increase in the life expectancy of Taiwanese, which affects the changes in the number of family pattern. As Sally and Alan(2008) mentioned, that the young and the old have become more vulnerable as a result of this geographic separation. the young experience limited contact with their elder family members who, historically, have been present to support their growth and learning, introduce values and offer wisdom, skills and unqualified love and understanding, older adults experience limited contact with younger family members. Bothe groups lose the special, dependable support offered by the family member from the opposite end of the life continuum. [2]

TABLE I: TAIWAN FAMILY PATTERN

\begin{tabular}{|c|c|c|c|c|c|c|c|c|c|}
\hline \multirow{3}{*}{ - } & \multicolumn{9}{|c|}{ items } \\
\hline & \multicolumn{2}{|l|}{ single } & \multirow[t]{2}{*}{ couple } & \multicolumn{2}{|c|}{$\begin{array}{l}\text { Single nu } \\
\text { parent }\end{array}$} & $\begin{array}{l}\text { nuclear } \\
\text { family }\end{array}$ & $\begin{array}{l}\text { grandparent } \\
\text { grandson }\end{array}$ & \multirow{2}{*}{$\begin{array}{l}\begin{array}{l}\text { three } \\
\text { generation }\end{array} \\
2 \quad 15.48\end{array}$} & \multirow{2}{*}{$\begin{array}{r}\text { others } \\
4.8\end{array}$} \\
\hline & 2001 & 10.73 & & 13.03 & 7.73 & 47.12 & 1.12 & & \\
\hline & 2006 & 10.54 & & 15.03 & 8.63 & 44 & 1.10 & 14.58 & 5.46 \\
\hline 2011 & 10.12 & & 170.5 & 9.31 & & 40.19 & 1.23 & 15.13 & 6.97 \\
\hline 2016 & 12.09 & & 18.98 & 10.09 & & 35.96 & 1.13 & 13.83 & 7.91 \\
\hline
\end{tabular}

In Seedfeldt's (1989/2008) study, it is pointed out that through the participation of intergenerational learning, interactions between different generations can be enhanced, and different generations can understand each other's differences, thereby enhancing the positive attitudes of different generations. [3] The Scottish Charitable Incorporated Organization, SCIO (2019) mentioned, intergenerational practice aims to bring people together in purposeful, mutually beneficial activities which promote greater understanding and respect between generations and contribute to building more cohesive communities. [4] Moreover, Ohsako (2002) believes that intergenerational learning can help to promote contacts from different 
generations, and to demonstrate social integration through mutual learning [5]. In summary, Aging society with fewer children will affect the family pattern, which will reduce the chances of getting along with the younger generation and the older generation, which will lead to the alienation of the generations and the creation of specific myths and stereotypes. Intergenerational learning allows different generations of people to participate in learning together, to enhance communication and interaction between different generations through learning, to eliminate each other's stereotypes through further understanding, so that both sides can face life problems together and challenge.

Therefore, providing intergenerational learning opportunities is the good way for young people to interact with the elderly, helping to solve aged social problems and providing young people with the ability to adapt to the elderly population. According to Mariano and Matthew (2014) mentioned that a multigenerational classroom is deemed to be one in which some of its members from various generations have a certain degree of generational awareness of belonging to different/ same generations. Against attaching a specific set of attitudes beliefs and behaviors to people according to their generational affiliation. [6] Therefore, it is the dynamic relation between intergenerational needs to be taken into account when considering multigenerational classrooms.

However, we also know that young people's family values build from the family and parents, then set their perspective on senior age. As Constantin (2014) mentioned the generic paradigm of intergenerational leaning is based on the family learning framework. [7] This article want to understand whether the family values of college students will be affected under the trend of family pattern change, and further explore whether family values have an impact on the willingness to learn, especially for intergenerational learning courses.

However, there is very limited research on the willingness of college students to participate in intergenerational learning courses in the literature. Based on the intergenerational learning should be promoted for all the knowledge fields: cognitive, emotional and spiritual (Ivona \& Constantin, 2012) [8] The aim of this study was to survey the effect of willingness to participate in family value to intergenerational learning program among college students to answer the following questions:

1) What are the family values of students and their willingness to participate in intergenerational learning courses?

2) Are there differences in family values between college students with different background variables?

3) Are there differences in the willingness of college students with different backgrounds to participate in intergenerational learning courses?

4) Is there any correlation between the family values of college students and their willingness to participate in intergenerational learning courses?

\section{METHOD}

\section{A. Study Design}

This study employed a Questionnaire.The conceptual framework of this study is presented in Fig. 1.

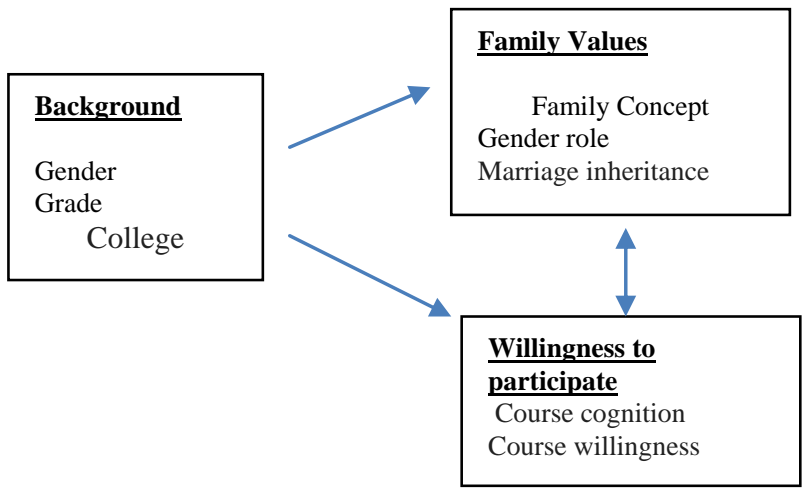

Fig. 1. Conceptual framework.

\section{B. Participants}

Participants were recruited from the 12,959 students in the second semester of the Private University, and selected 668 students from the first grade to the fourth grade.

\section{Questionnaire}

This study used questionnaires for the "Family Value Scale for College Students", and referred from "Family Value Scale" used by Hsu (2012). [9] The scale of this study was 5-point Likert scale with a median of 3, an average between 1.44 and 4.17, and a standard deviation between .572 and 1.08.After factor analysis, the total explanatory variation was $62.947 \%$.

\section{Analysis}

To test the hypothesized associations between variables, data were analyzed using SPSS Version 22 for windows. It used descriptive statistics, standard mean deviation, on-way ANOVA, contingency coefficient, and multiple regression analysis to analysis the data.

\section{RESULTS}

\section{A. Background}

Taking a sample of 668 students, according to Table II, we can understand the background variable include gender, grade, college and family style, and ratio with them.

About the "Course Cognitive Situation", a two-point scale and multiple-choice questions are used to investigate to understand the subject's perception of the intergenerational learning curriculum. In the 668 valid questionnaires, the average number of "course cognitions" was .34 , which was lower than the average of .05 , indicating that most of the subjects had lower awareness of intergenerational learning courses. As Table III mentions, up to $80 \%$ of the subjects have not listened to intergenerational learning courses, and more than $90 \%$ of the subjects have not taken the intergenerational study course, but $80 \%$ of the students agree that the school will provide more intergenerational learning courses. The results of this study was broadly consistent with the research by Hsu (2016). [10] According to the research, most of the subjects have not heard of and studied the intergenerational learning courses, and still agree that the school has more such courses, the reasons are shown in Table 
III, most of them are subject to The testers want to enhance their understanding of their elders through intergenerational learning courses. Therefore, intergenerational learning courses have the need for promotion.

TABLE II: BACKGROUND ANALYSIS

\begin{tabular}{llll}
\hline Background & & Number & percentage \\
\hline \multirow{2}{*}{ Gender } & Man & 290 & 43.4 \\
\cline { 2 - 4 } & Female & 378 & 56.6 \\
\hline \multirow{2}{*}{$\begin{array}{l}\text { Grade } \\
\text { (under-graduate) }\end{array}$} & Freshman & 199 & 29.8 \\
\cline { 2 - 4 } & second grade & 226 & 33.8 \\
\cline { 2 - 4 } & Third grade & 127 & 19.0 \\
\cline { 2 - 4 } & Senior & 116 & 17.4 \\
\hline College & Liberal Arts & 96 & 14.4 \\
\hline
\end{tabular}

\begin{tabular}{llll}
\hline & Science & 62 & 9.3 \\
\cline { 2 - 4 } & Engineering & 98 & 14.7 \\
\cline { 2 - 4 } & Management & 151 & 22.6 \\
\cline { 2 - 4 } & Social Sciences & 117 & 17.5 \\
\cline { 2 - 4 } & Agricultural & 62 & 9.3 \\
\cline { 2 - 4 } & Creative Design and Arts & 58 & 8.7 \\
\cline { 2 - 4 } & Law & 24 & 3.6 \\
\hline Family Style & one-parent family & 67 & 10.0 \\
\cline { 2 - 4 } & core family & 488 & 73.1 \\
\cline { 2 - 4 } & Three generation family & 113 & 16.9 \\
\hline$n=668$ & & & \\
\hline
\end{tabular}

TABLE III: ANALYSIS OF THE SUBJECT "COURSE COGNITIVE SitUATION

\begin{tabular}{|c|c|c|c|}
\hline $\begin{array}{l}\text { Course Cognitive } \\
\text { Situation }\end{array}$ & Answer & $\mathrm{n}$ & $\%$ \\
\hline \multirow{2}{*}{$\begin{array}{l}\text { Q1. Have you ever heard } \\
\text { of the "Intergenerational } \\
\text { Learning" course? }\end{array}$} & $\mathrm{Y}$ & 130 & 19.5 \\
\hline & $\mathrm{F}$ & 538 & 80.5 \\
\hline \multirow{2}{*}{$\begin{array}{l}\text { Q2. Have you ever } \\
\text { studied } \\
\text { "Intergenerational } \\
\text { Learning" course? }\end{array}$} & $\mathrm{Y}$ & 23 & 3.4 \\
\hline & $\mathrm{F}$ & 645 & 96.6 \\
\hline \multirow{2}{*}{$\begin{array}{l}\text { Q3. Do you agree that } \\
\text { universities will open } \\
\text { more "intergenerational } \\
\text { learning" courses? }\end{array}$} & $\bar{Y}$ & 536 & 80.2 \\
\hline & $\mathrm{F}$ & 132 & 19.8 \\
\hline \multirow{5}{*}{$\begin{array}{l}\text { Q4. Endorsing the } \\
\text { reasons for setting up } \\
\text { more intergenerational } \\
\text { learning courses in } \\
\text { schools }\end{array}$} & Can improve understanding of elders & 484 & 49.8 \\
\hline & There are elders in the family to take care of & 179 & 18.4 \\
\hline & I want to work for the elderly in the future. & 79 & 8.1 \\
\hline & Interested in the course content & 196 & 20.2 \\
\hline & others & 32 & 3.5 \\
\hline \multirow[t]{5}{*}{ others } & Don't like to interact with elders & 26 & 12.4 \\
\hline & Worried about communication problems with elders & 59 & 28.1 \\
\hline & Worried that more effort is needed in the class & 44 & 21.0 \\
\hline & Not interested in the course content & 72 & 34.3 \\
\hline & others & 9 & 4.3 \\
\hline
\end{tabular}

In addition, about the "willingness to participate ", in the 668 valid questionnaires, the average was 3.86 , which was between "normal" and "consent", indicating that most of the subjects were willing to take the inter-generational learning course. The question on "In the classroom, whether you are willing to accept the elders to teach you professional knowledge and skills" and "In the classroom, whether you accept the elders to share their own life stories" has the highest score, indicating that the subjects are willing to learn the knowledge and experience from the elders in the classroom; and the lowest score for "whether you are willing to work with the elders to complete the homework".

Moreover, in order to understand whether the different background variables of the subjects differed at the "family values" and " course cognition", the researchers used statistical analysis to determine the difference between mean and one-way analysis of variance. The following were analysis of the differences between gender, grades, colleges, and family type.

\section{B. Gender}

TABLE IV: ANALYSIS OF THE DIFFERENCE BETWEEN GENDER, "FAMILY VAlues", "COURSE COGNITION" AND "COURSE WiLLINGNESS"

\begin{tabular}{|c|c|c|c|c|}
\hline Family values & Gender & $n$ & mean & $t$ \\
\hline \multirow{2}{*}{$\begin{array}{l}\text { Family } \\
\text { Concept }\end{array}$} & Man & 290 & \multicolumn{2}{|r|}{.248} \\
\hline & Female & 378 & & \\
\hline \multirow[t]{2}{*}{ Gender role } & Man & 290 & \multicolumn{2}{|r|}{$7.201 * * *$} \\
\hline & Female & 378 & & \\
\hline \multirow{2}{*}{$\begin{array}{l}\text { Marriage } \\
\text { inheritance }\end{array}$} & Man & 290 & \multicolumn{2}{|r|}{$2.986 * *$} \\
\hline & Female & 378 & & \\
\hline \multirow{2}{*}{$\begin{array}{l}\text { Overall family } \\
\text { values }\end{array}$} & Man & 290 & & \multirow[t]{2}{*}{$4.024 * * *$} \\
\hline & Female & 378 & & \\
\hline \multirow{2}{*}{$\begin{array}{l}\text { Course } \\
\text { cognition }\end{array}$} & Man & 290 & .3069 & \multirow[t]{2}{*}{$.254 * * *$} \\
\hline & Female & 378 & .3721 & \\
\hline \multirow{2}{*}{$\begin{array}{l}\text { Course } \\
\text { willingness }\end{array}$} & Man & 290 & .3751 & \multirow[t]{2}{*}{$-3.753 * * *$} \\
\hline & Female & 378 & .3935 & \\
\hline
\end{tabular}

Family values between college students with different background variables, Men tend to be more traditional in terms of "gender roles", "marriage inheritance" and "overall family values". Moreover, subjects differed by gender in terms of the "course cognition "and "course willingness" to a 
significant above .05 , that are, subjects of different genders in showed significant differences in the "course cognition" and course willingness, and "female". The average score is significantly higher than that of "male". Tt can be seen that "female" has a willingness to practice intergenerational learning courses on the "course cognition" and "course willingness" than "male". (refers to Table IV).

TABLE V: ANALysis Between GRAde AND "FAmily Values", "Course

\begin{tabular}{|c|c|c|c|c|c|}
\hline & Cogniti & AND “ & OURSE & LINGNESS & \\
\hline \multirow{2}{*}{$\begin{array}{l}\text { Family } \\
\text { values }\end{array}$} & \multirow[t]{2}{*}{ Grade } & \multirow[t]{2}{*}{$n$} & \multicolumn{2}{|c|}{ Analysis of variance } & \multirow[b]{2}{*}{ Post HOC } \\
\hline & & & $F$ & $p$-value & \\
\hline \multirow{4}{*}{$\begin{array}{l}\text { Family } \\
\text { Concept }\end{array}$} & Freshman & 199 & 4.424 & $.004 * *$ & $1>3$ \\
\hline & Sophomore & 226 & & & \\
\hline & Junior & 127 & & & \\
\hline & Senior & 116 & & & \\
\hline Gender rol & Freshman & & 5.112 & $.002 * *$ & \\
\hline
\end{tabular}

\begin{tabular}{|c|c|c|c|c|c|}
\hline Gender role & Freshman & 199 & 5.112 & $.002^{* *}$ & $\begin{array}{l}1>2 \\
1>3\end{array}$ \\
\hline & Sophomore & 226 & & & \\
\hline & Junior & 127 & & & \\
\hline & Senior & 116 & & & \\
\hline \multirow{4}{*}{$\begin{array}{l}\text { Marriage } \\
\text { inheritance }\end{array}$} & Freshman & 199 & 3.129 & $.025^{*}$ & $1>3$ \\
\hline & Sophomore & 226 & & & \\
\hline & Junior & 127 & & & \\
\hline & Senior & 116 & & & \\
\hline \multirow{4}{*}{$\begin{array}{l}\text { Overall } \\
\text { family } \\
\text { values }\end{array}$} & Freshman & 199 & 7.059 & $.000 * * *$ & $1>3$ \\
\hline & Sophomore & 226 & & & \\
\hline & Junior & 127 & & & \\
\hline & Senior & 116 & & & \\
\hline \multirow{5}{*}{$\begin{array}{l}\text { Course } \\
\text { cognition }\end{array}$} & Freshman & 190 & 5.954 & $.001 * *$ & $3>1$ \\
\hline & & 199 & & & $4>1$ \\
\hline & Sophomore & 226 & & & \\
\hline & Junior & 127 & & & \\
\hline & Senior & 116 & & & \\
\hline \multirow{4}{*}{$\begin{array}{c}\text { Course } \\
\text { willingness }\end{array}$} & Freshman & 199 & 3.892 & $.009 * *$ & $4>1$ \\
\hline & Sophomore & 226 & & & \\
\hline & Junior & 127 & & & \\
\hline & senior & 116 & & & \\
\hline
\end{tabular}

\section{Grade}

Depends on the Table V, the results of this study in general, the family value of the "freshman" students is often more traditional than the "third grad" students. According to the Table V, the difference in "course cognition" is significantly higher than the level of .05 or above, that is, subjects of different grades are significantly more prominent in the "course cognition" difference. In order to understand the difference, Scheffe's post hoc test comparative analysis found that the average scores of the juniors and seniors were significantly higher than those of the freshmen. This result shows that "juniors" and "seniors" have higher intergenerational learning course awareness than "freshmen", and "seniors" have higher willingness to participate intergenerational learning course than "freshmen"

\section{College}

TABLE VI: ANALYSIS BETWEen COLLEGE, "FAMILy VALUES" "COURSE COGNITION" AND "COURSE WILLINGNESS"

\begin{tabular}{|c|c|c|c|c|c|}
\hline \multirow{2}{*}{$\begin{array}{l}\text { Family } \\
\text { values }\end{array}$} & \multirow[t]{2}{*}{ College } & \multirow[t]{2}{*}{$n$} & \multicolumn{3}{|c|}{ Analysis of variance } \\
\hline & & & $F$ & $p$. & $P$-hoc \\
\hline \multirow[t]{8}{*}{ Family concept } & Liberal Arts & 96 & 2.137 & $.038 *$ & \\
\hline & Science & 62 & & & \\
\hline & Engineering & 98 & & & \\
\hline & Management & 151 & & & \\
\hline & Social Sciences & 117 & & & \\
\hline & Agricultural & 62 & & & \\
\hline & Creative Design \& Arts & 58 & & & \\
\hline & Law & 24 & & & \\
\hline \multirow[t]{8}{*}{ Gender role } & Liberal Arts & 96 & 3.443 & $.001 * *$ & \\
\hline & Science & 62 & & & \\
\hline & Engineering & 98 & & & \\
\hline & Management & 151 & & & \\
\hline & Social Sciences & 117 & & & \\
\hline & Agricultural & 62 & & & \\
\hline & Creative Design \& Arts & 58 & & & \\
\hline & Law & 24 & & & \\
\hline \multirow{8}{*}{$\begin{array}{l}\text { Marriage } \\
\text { inheritance }\end{array}$} & Liberal Arts & 96 & 1.566 & .143 & \\
\hline & Science & 62 & & & \\
\hline & Engineering & 98 & & & \\
\hline & Management & 151 & & & \\
\hline & Social Sciences & 117 & & & \\
\hline & Agricultural & 62 & & & \\
\hline & Creative Design \& Arts & 58 & & & \\
\hline & Law & 24 & & & \\
\hline \multirow{8}{*}{$\begin{array}{r}\text { Overall family } \\
\text { values }\end{array}$} & Liberal Arts & 96 & 2.677 & $.01 *$ & \\
\hline & Science & 62 & & & \\
\hline & Engineering & 98 & & & \\
\hline & Management & 151 & & & \\
\hline & Social Sciences & 117 & & & \\
\hline & Agricultural & 62 & & & \\
\hline & Creative Design \& Arts & 58 & & & \\
\hline & Law & 24 & & & \\
\hline \multirow{8}{*}{$\begin{array}{l}\text { course } \\
\text { cognition }\end{array}$} & Liberal Arts & 96 & 6.981 & $.000^{* * *}$ & \multirow{8}{*}{$\begin{array}{l}5>3 \\
5>6 \\
5>8\end{array}$} \\
\hline & Science & 62 & & & \\
\hline & Engineering & 98 & & & \\
\hline & Management & 151 & & & \\
\hline & Social Sciences & 117 & & & \\
\hline & Agricultural & 62 & & & \\
\hline & Creative Design \& Arts & 58 & & & \\
\hline & Law & 24 & & & \\
\hline \multirow{8}{*}{$\begin{array}{l}\text { Course } \\
\text { willingness }\end{array}$} & Liberal Arts & 96 & 2.621 & $.011^{*}$ & \\
\hline & Science & 62 & & & \\
\hline & Engineering & 98 & & & \\
\hline & Management & 151 & & & \\
\hline & Social Sciences & 117 & & & \\
\hline & Agricultural & 62 & & & \\
\hline & Creative Design \& Arts & 58 & & & \\
\hline & Law & 24 & & & \\
\hline
\end{tabular}

According to the Table VI, the differences in the "family concept", "gender role" and "overall family values" of the subjects are all at the confidence interval above .05 , that is, the students in different colleges were in the "family concept". Significant differences in "gender role" and " overall family values ". 
In addition, the difference in the "course cognition" and "course willingness" were above the confidence interval .05, that is, the subjects of different colleges show significant differences in the "course cognition ". In order to understand the difference, Scheffe's post hoc test comparative analysis found that the average scores of the "Social Sciences" was higher than that of the college as "Agricultural" and "Law". It showed that the subjects of the "Social Sciences College" had higher intergenerational learning curriculum perceptions than those of the "Agricultural College" and "Law School" on the "course cognition".

About the correlation between the family values of college students and their willingness to participate in intergenerational learning courses, as far as the overall value of "family values" is concerned, the correlation coefficient with the overall level of willingness to participate in intergenerational learning courses is .841 , which is a significant level $(p<.01)$, showing family values and willingness to participate in intergenerational learning courses have a close relationship (see to Table VII).

TABLE VII: ANALYSIS OF THE RELATIONSHIP BETWEEN FAMILY VALUES AND WILLINGNESS TO PARTICIPATE

\begin{tabular}{|c|c|c|c|c|c|}
\hline & & \multicolumn{2}{|c|}{ Family values } & \multirow[b]{2}{*}{ Marriage inheritance } & \multirow[b]{2}{*}{ overall } \\
\hline & & Family concept & Gender role & & \\
\hline \multirow[t]{3}{*}{ Willingness to participate } & Course cognition & $.437 * * *$ & $.288^{* * * *}$ & .288 & $\begin{array}{l}.530 * * \\
*\end{array}$ \\
\hline & Course willingness &. $.757 * *$ & .591 & $.687 * *$ & $.825 * *$ \\
\hline & overall & $.779 * * *$ & .605 & $.703 * * *$ & $\begin{array}{l}.841^{* *} \\
*\end{array}$ \\
\hline
\end{tabular}

$* p<.05, * * p<.01 ; n=668$

\section{DISCUSSION}

This research shows that the effect of willingness to participate in family value to intergenerational learning program among college students. According to the study, the family values of college students generally tend to be traditional. The family values of college students include three aspects: family concept, gender role, and marriage inheritance. Among them, the family concept is the most traditional, and the gender role is the most modern. It is thus known that in this rapidly changing society, college students still have a certain degree of traditional conception of family values, especially in the family, coordination, interaction and respect of family members, and still maintain a high degree of attention; In this era of paying attention to gender equality, it is still paid attention to in the field of learning. Undergraduate students can learn from each other in different classes in the classroom. It can cultivate the tacit understanding of peers in an invisible way, and it is also beneficial to eliminate the traditional stereotypes about gender.

According to the study, the overall family values, gender roles and marriage inheritance of "male" tend to be more traditional than "female"; the overall family values and family values and marriage inheritance of "first year" are more "professional" trends. Tradition, at the gender role level, it tends to be more traditional than the sophomore and junior. It can be seen from the above that in the family values of college students, the family values of men tend to be more traditional than women. The researchers reasoned that the male students still feel the expectation and pressure of the whole society on men, and the family values of male college students tend to be traditional; In the different grades, the family values of the freshman are more traditional than junior. The researchers concluded that the reason may be that freshmen have just entered college and are not completely separated from their families, so family values are still traditional.

In addition, according to the study, although college students generally lack understanding of intergenerational learning courses, most college students still agree that schools should open more intergenerational learning courses. The researchers concluded that the possible reason is that the sampling university lacks intergenerational learning courses and less promotion information, which leads to a lower awareness of college students on intergenerational learning courses; most college students still believe that the main reason for setting up intergenerational learning courses in schools is to promote understanding of the elderly. Researchers infer their possible reasons. For college students, they generally believe that Taiwan has entered the stage of aged society. If campus provides courses related to the elderly, it should help them understand the aging, learning and communication of the elderly.

Moreover, according to the study, the "course cognition" of "female" is higher than that of "male"; the curriculum awareness of "junior" and "senior" is higher than that of "freshman"; the "Social Sciences" is higher than that of Agriculture and Law School. The researchers concluded that the possible reason that "female" students are higher than "male" students in curriculum cognition is that female students are more willing to participate in different types of courses and activities, giving them more opportunities to obtain information about intergenerational learning course.

According to our study, it mentioned different "gender", "grade" and "college" showed significant differences in the "Course cognition". The reason was higher grades of college students, the more opportunities there are for the course, and the more important information is obtained for intergenerational learning courses. Relevant information on the course of study, the College of the "Social Science" is higher than the "Agricultural College" and the "Law School", the researchers concluded that the possible reason is that the College of Social Sciences has more courses related to people and society. Mastering the changes in Taiwan's society at this stage will enable students to better understand the intergenerational learning curriculum.

Otherwise, as the study mentioned that the question on "In the classroom, whether you are willing to accept the elders to 
teach you professional knowledge and skills" and "In the classroom, whether you accept the elders to share their own life stories" has the highest score, indicating that the subjects are willing to learn the knowledge and experience from the elders in the classroom; and the lowest score for "whether you are willing to work with the elders to complete the homework", the possible reason is that the subject has not yet had the experience of working with the elders, so there is still a specific stereotype, worried that the teacher will ask for more efforts with the elderly. College students believe that the elderly have certain work experience and life experience, and can provide college students with ideas and suggestions in the workplace and life experience. If we can narrow the gap between generations through mutual guidance and intergenerational learning courses, we believe that we can effectively improve communication problems between generations and create more learning models.

Finally, According to the study, in the family values of the university students, the "family concept" and the "gender role" are positively related to the "course cognition" of the willingness to participate in intergenerational learning courses; "family concept" and " marriage inheritance"also a positive correlation with the willingness to participate in intergenerational learning courses. As the family values of college students become more traditional, the willingness to participate in intergenerational learning courses is higher. The more traditional the family values of college students, the more important they are to family members, and they are willing to maintain a certain interaction with family members. The researchers reasoned that this type of college students can easily establish good interaction with others and attach importance to harmony in groups and, had higher willingness to participate in intergenerational learning courses.

\section{CONCLUSION}

It can be safely concluded that the family Value effect the willingness to participate in Intergenerational learning program among college students to a significant extent. Although college students generally lack understanding of intergenerational learning courses, most students still agree that schools should open more intergenerational learning courses who want to enhance their understanding of their elders through intergenerational learning courses. Findings from this study suggest that to Intergenerational learning courses offered by universities should allow older people to participate in the curriculum and provide mutual understanding and exchange of values among generations. Future research should continue to create opportunities and themes in intergenerational curricula, including interactions and communication between generations, which will promote students' family values and willingness to serve the elderly.

\section{CONFLICT OF INTEREST}

"The authors declare no conflict of interest".

\section{AUTHOR CONTRIBUTIONS}

Lin conducted the research and analyzed the data; Chen wrote the paper; all authors had approved the final version.

\section{REFERENCES}

[1] Statistics Department of the Taiwan's Ministry of the Interior. (2018). Directorate-General of Budget, Accounting and Statistics Executive Yuan, Taiwan. [Online]. Available: https://www.moi.gov.tw/english/

[2] N. Sally and H. Alan," Intergenerational learning and the contributions of older people," Ageing Horizons, vol. 8, pp. 31-39, 2008.

[3] C. Seedfeldt, "Intergenerational programs - Impact on attitudes," Journal of Children in Contemporary Society, vol. 20, no. 3-4, pp. 185-194, 1989/2008.

[4] The Scottish Charitable Incorporated Organization, SCIO. (August 2019). [Online]. Available: https://generationsworkingtogether.org/

[5] T.Ohsako. (2002). The role of intergenerational program in promoting lifelong learning for all ages. [Online]. Available: http://www.unesco.org/education/uie/pdf/uiestud36.pdf

[6] S. Mariano and K. Matthew, "Intergenerational learning in higher education: making the case for multigenerational classrooms," Educational Gerontology, vol. 40, no.7, pp. 473-485, 2014.

[7] Constantin, International Conference on ICICKM 2014 11th International Conference on Intellectual Capital, Knowledge Management And Organisational Learning Sydney, Australia, November, 83-91, 2014.

[8] O. Ivona and B. Constantin, "Intergenerational learning in ageing societies," presented at the International Conference on Intellectual Capital, Knowledge Management and Organizational Learning, Bogota, Columbia, October, pp. 193-200,2012.

[9] C. C. Hsu, "A study on the relationship between the family values and the love attitudes of students of University of Pingtung area," M.S. dissertation, Nation Pingtung University, Pingtung, Taiwan, 2012.

[10] P. T. Hsu, "A study on the BA students' attitude and enrolling will on the intergenerational learning courses," M.S. dissertation, Nation Chung Cheng University, Chiayi, Taiwan, 2016.

Copyright $(2019$ by the authors. This is an open access article distributed under the Creative Commons Attribution License which permits unrestricted use, distribution, and reproduction in any medium, provided the original work is properly cited (CC BY 4.0).

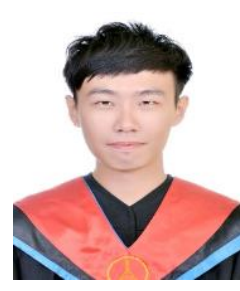

Yu Jen Lin was born in April, 1990 in Taiwan. He is currently a substitute teacher in Hou-Zong Senior High School, Taiwan. His specialty is Chinese literature and his research direction is intergenerational learning.

Tai Fen Chen was born in 1973 in Taiwan. She received the Ph.D. in adult education in National Chung Cheng University, Taiwan. She also is an assistant professor at the Graduate Institute of Education, Tunghai University, Taiwan. Her research interests are in elderly education and learn, intergenerational learning. 